ARGONNE NATIONAL LABORATORY

9700 South Cass Avenue

Argonne, Illinois 60440

CALCULATIONS OF k FOR SOME SMALL $\mathrm{U}^{233}-, \mathrm{U}^{235}-$, AND $\mathrm{Pu}^{239}-\mathrm{FUELED}$

FAST REACTORS

by

W. G. Davey

Idaho Division

February 1964

Operated by The University of Chicago under

Contract W-31-109-eng-38 with the

U. S. Atomic Energy Commission 


\section{DISCLAIMER}

This report was prepared as an account of work sponsored by an agency of the United States Government. Neither the United States Government nor any agency Thereof, nor any of their employees, makes any warranty, express or implied, or assumes any legal liability or responsibility for the accuracy, completeness, or usefulness of any information, apparatus, product, or process disclosed, or represents that its use would not infringe privately owned rights. Reference herein to any specific commercial product, process, or service by trade name, trademark, manufacturer, or otherwise does not necessarily constitute or imply its endorsement, recommendation, or favoring by the United States Government or any agency thereof. The views and opinions of authors expressed herein do not necessarily state or reflect those of the United States Government or any agency thereof. 


\section{DISCLAIMER}

Portions of this document may be illegible in electronic image products. Images are produced from the best available original document. 
TABLE OF CONTENTS

$\underline{\text { Page }}$

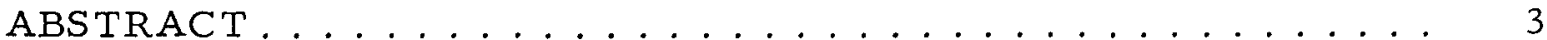

I. INTRODUCTION. .................... 3

II. DERIVATION OF THE CROSS-SECTION SET ......... 3

III. REACTOR COMPOSITIONS AND CALCULATIONS ....... 4

A. The Los Alamos Assemblies . . . . . . . . . . . . . 4

B. The VERA Assemblies ................ 6

C. EBR-I MarkIV . . . . . . . . . . . . . . 7

D. The RAPSODIE Assembly in ZPR-III . . . . . . . . 8

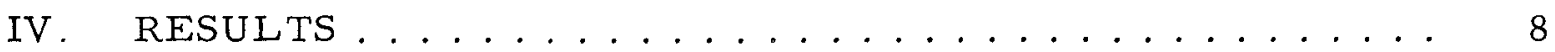

V. DISCUSSION AND CONCLUSIONS ............. 9

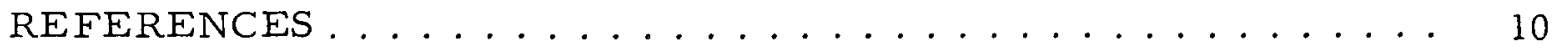

APPENDIX I. GROUP CROSS SECTIONS FOR COPPER ....... 11 


\section{LIST OF TABLES}

No. Title

Page

I. Core and Blanket Compositions in VERA Assemblies 9A, 10A, and $11 \mathrm{~A} \ldots \ldots \ldots 6$

II. VERA Critical Masses and Corrections . . . . . . . . . . 7

III. EBR-I Mark-IV Core Composition and Dimensions. . . . . . . 7

IV. EBR-I Mark-IV Blanket Compositions and Dimensions ..... 8

V. RAPSODIE Mockup Composition and Dimensions ....... 8

VI. Calculated Values of $k \ldots \ldots \ldots$. . . . . . . . . 


\title{
CALCULATIONS OF $\mathrm{k}$ FOR SOME SMALL $\mathrm{U}^{233}-, \mathrm{U}^{235}-$, AND $\mathrm{Pu}^{239}-$ FUELED \\ FAST REACTORS
}

by

W. G. Davey

\begin{abstract}
Values of the multiplication constant, $k$, have been calculated for a number of small $\mathrm{U}^{233}-, \mathrm{U}^{235}$-, and $\mathrm{Pu}^{239}$ fueled fast reactors through use of a cross-section set previously used by the author for investigation of a number of $\mathrm{U}^{235}$-fueled ZPR-III as semblies. (1-3) The reactors considered in the present report are (a) GODIVA, TOPSY, JEMIMA, JEZEBEL, POPSY, and $U^{233}$ as semblies constructed at Los Alamos; (b) three plutonium-graphite critical assemblies constructed with the reactor VERA at AWRE, Aldermaston, England; (c) the plutonium-fueled Mark-IV loading of the EBR-I reactor at Idaho Division of ANL; and (d) a plutoniumand $U^{235}$-fueled mockup in ZPR-III of a proposed French reactor, RAPSODIE.
\end{abstract}

\section{INTRODUCTION}

A comparison of measured and calculated parameters of $\mathrm{U}^{235}$ fueled ZPR-III fast critical assemblies was previously carried out by the author $(1-3)$ through use of a 16 -group cross-section set which is a modification of the set of Yiftah, Okxent, and Moldauer (YOM).(4) In that study, which covered core volumes ranging from 50 to 660 liters and critical masses from 130 to $580 \mathrm{~kg}$ of $\mathrm{U}^{235}$, the critical masses could be calculated to an accuracy not worse than $6 \frac{1}{2} \%$. In the present study, the same crosssection set and computational methods have been used to calculate the values of $\mathrm{k}$ for a number of small, dense, $\mathrm{U}^{233}$ - and $\mathrm{U}^{235}$-fueled reactors constructed at Los Alamos and for eight $\mathrm{Pu}^{239}$-fueled systems constructed at Los Alamos, Aldermaston, and the Idaho Division of Argonne National Laboratory.

\section{DERIVATION OF THE CROSS-SECTION SET}

The derivation of the cross-section set has been described in detail (1) (also Appendix I of reference 3). Briefly, it consists of the YOM Set 
with: (a) values of $\alpha$ for $\mathrm{U}^{233}, \mathrm{U}^{235}$, and $\mathrm{Pu}^{239}$ modified to agree with the measurements of Hopkins and Diven; ${ }^{(5)}$ (b) the values of $\nu$ for $\mathrm{U}^{235}$ modified in accordance with recent measurements; $(6-8)$ and (c) the transport and elastic removal cross sections of steel and aluminum modified in an approximate manner to allow for the effects of strong resonances in these materials. $(9,10)$

In addition to these data, 16-group cross sections for copper have been added.(11) These are given in Appendix I.

\section{REACTOR COMPOSITIONS AND CALCULATIONS}

The values of $k$ were calculated by converting (when necessary) the experimental critical configuration to the equivalent, idealized spherical geometry and then finding $k$ for this geometry by means of the DSN neutron transport code. When necessary, corrections to the critical mass were applied for core heterogeneity and some other small effects, thus obtaining critical masses of homogeneous systems of regular geometry. The shape factor used to correct for the core geometry is defined as the ratio of the critical masses of spherical and cylindrical reactors of identical composition, and it is a function of both the core size and the length-to-diameter ratio of the cylindrical core. The method of estimating the shape factors was identical with that used in reference 1 and will not be discussed here.

In the previous study $(1)$ all calculations were made with the DSN code in the $\mathrm{S} 4$ approximation. This approximation was accurate for the larger reactors previously considered, but is inaccurate for some of the small reactors examined here. Some $\mathrm{S} 4$ and $\mathrm{S} 8$ calculations were carried out to estimate the effect of the degree of approximation upon the calculated value of $k$. All the values of $k$ were then corrected to those that would be obtained by means of S8 calculations.

The reactor compositions and geometries are discussed more fully below.

\section{A. The Los Alamos Assemblies}

All these reactors have been considered by Roach (12) and, when necessary, he has estimated the critical masses of homogeneous spherical systems. The idealized compositions and dimensions derived by Roach have been used here. They are given below.

\section{GODIVA: A bare highly enriched uranium sphere.}

The composition is $93.8 \% \mathrm{U}^{235}$ and $6.2 \% \mathrm{U}^{238}$; the effective density of $\mathrm{U}^{235}$ is $17.59 \mathrm{~g} / \mathrm{cm}^{3}$; the critical mass is $48.7 \mathrm{~kg} \mathrm{U} \mathrm{U}^{235}$, and the core radius is $8.71 \mathrm{~cm}$. S4 and $\mathrm{S} 8$ calculations were run. 
2. TOPSY: A natural uranium reflected highly enriched uranium sphere.

The core was $94.1 \% \mathrm{U}^{235}$ and $5.9 \% \mathrm{U}^{238}$; the effective $\mathrm{U}^{235}$ den-

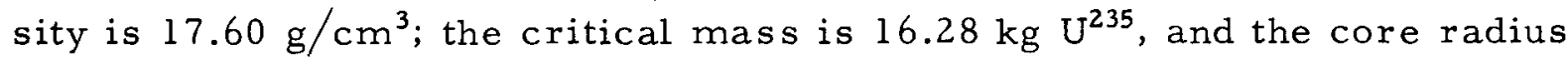
is $6.04 \mathrm{~cm}$. The reflector is $9.0 \mathrm{in}$. of natural uranium at a density of $19.0 \mathrm{~g} / \mathrm{cm}^{3}$.

3. JEMIMA 53.6: A bare 53.6\% enriched uranium cylinder.

The idealized composition is a sphere of $53.6 \% \mathrm{U}^{235}$, and $46.4 \%$ $\mathrm{U}^{238}$; the effective $\mathrm{U}^{235}$ density is $10.02 \mathrm{~g} / \mathrm{cm}^{3}$; the critical mass is $75.0 \mathrm{~kg}$ $\mathrm{U}^{235}$, and the core radius is $12.14 \mathrm{~cm}$.

4. JEMIMA 37.7: A bare 37.7\% enriched uranium cylinder.

The idealized composition is a sphere of $37.7 \% \mathrm{U}^{235}$ and $62.3 \%$ $\mathrm{U}^{238}$; the effective $\mathrm{U}^{235}$ density is $7.07 \mathrm{~g} / \mathrm{cm}^{3}$; the critical mass is $92.4 \mathrm{~kg}$ $\mathrm{U}^{235}$, and the core radius is $14.61 \mathrm{~cm}$.

5. JEMIMA 29.0: A bare $29.0 \%$ enriched uranium cylinder.

The idealized composition is a sphere of $29.0 \% \mathrm{U}^{235}$ and $71.0 \%$ $\mathrm{U}^{238}$; the effective $\mathrm{U}^{235}$ density is $5.45 \mathrm{~g} / \mathrm{cm}^{3}$; the critical mass is $109.3 \mathrm{~kg}$ $\mathrm{U}^{235}$, and the core radius is $16.85 \mathrm{~cm}$.

6. JEZEBEL: A bare plutonium sphere.

The core is entirely $\mathrm{Pu}^{239}$ at a density of $15.56 \mathrm{~g} / \mathrm{cm}^{3}$. The critical mass is $16.22 \mathrm{~kg} \mathrm{Pu}{ }^{239}$, and the core radius is $6.29 \mathrm{~cm}$. S4 and S8 calculations were run.

7. POPSY: A natural uranium-reflected plutonium sphere.

The core is $\mathrm{Pu}^{239}$ at a density of $15.67 \mathrm{~g} / \mathrm{cm}^{3}$; the critical mass is $5.74 \mathrm{~kg} \mathrm{Pu}{ }^{239}$, and the core radius is $4.44 \mathrm{~cm}$. The reflector is 9.5 in. of natural uranium at a density of $18.97 \mathrm{~g} / \mathrm{cm}^{3}$. S4 and $S 8$ calculations were run.

8. $\frac{\mathrm{Pu} / \mathrm{U}: \text { A reflected heterogeneous cylinder of plutonium and }}{\text { depleted uranium. }}$

The idealized composition is a homogeneous $\mathrm{Pu}^{239} / \mathrm{Nickel} / \mathrm{U}^{238}$ sphere with $\rho\left(\mathrm{Pu}^{239}\right)=3.81 \mathrm{~g} / \mathrm{cm}^{3}, \rho($ Nickel $)=0.174 \mathrm{~g} / \mathrm{cm}^{3}$ and $\rho\left(\mathrm{U}^{238}\right)=$ $13.87 \mathrm{~g} / \mathrm{cm}^{3}$. The critical mass is $20.09 \mathrm{~kg} \mathrm{Pu}{ }^{239}$, and the core radius is $10.80 \mathrm{~cm}$. The reflector is $7.5 \mathrm{in}$. of $\mathrm{U}^{238}$ at a density of $19.0 \mathrm{~g} / \mathrm{cm}^{3}$. 
9. $\mathrm{U}^{233} / \mathrm{U}^{238}:$ A natural uranium-reflected $\mathrm{U}^{233}$ sphere.

The core is a $5.04-\mathrm{cm}$-radius sphere of $9.705 \mathrm{~kg}$ of $\mathrm{U}^{233}$ and $0.172 \mathrm{~kg}$ of $\mathrm{U}^{238}$. The reflector is $0.885 \mathrm{in}$. of natural uranium at a density of $18.9 \mathrm{~g} / \mathrm{cm}^{3}$.

10. $\mathrm{U}^{233} / \mathrm{U}^{235}:$ An enriched uranium-reflected $\mathrm{U}^{233}$ sphere.

The core is identical with the $\mathrm{U}^{233} / \mathrm{U}^{238}$ core. The reflector is 0.458 in. of $93.3 \%$ enriched uranium at a density of $18.8 \mathrm{~g} / \mathrm{cm}^{3}$.

B. The VERA Assemblies

The compositions and critical dimensions of a number of $\mathrm{U}^{235}$ - and $\mathrm{Pu}^{239}$-fueled fast critical assemblies have been reported recently by Weale et al. (13) Of these assemblies, numbers $9 \mathrm{~A}, 10 \mathrm{~A}$, and $11 \mathrm{~A}$ were reflected critical assemblies whose major core constituents were plutonium and carbon. Assembly $8 \mathrm{~A}$ was fueled with plutonium but did not reach criticality. The core and blanket compositions of VERA 9A, 10A, and $11 \mathrm{~A}$ are given in Table I. The blanket was the same composition for each as sembly.

Table I

CORE AND BLANKET COMPOSITIONS IN VERA ASSEMBLIES 9A 10A, AND $11 \mathrm{~A}$

\begin{tabular}{|c|c|c|c|c|c|c|c|c|c|}
\hline \multirow{2}{*}{ Region } & \multicolumn{9}{|c|}{ Composition of Region (atoms $/ \mathrm{cm}^{3}$ ) $\times 10^{-22}$} \\
\hline & $\mathrm{U}^{235}$ & $\mathrm{U}^{238}$ & $\mathrm{Pu}^{239}$ & $\mathrm{Pu}^{240}$ & $\mathrm{Cu}$ & $\mathrm{Fe}$ & $\mathrm{Cr}$ & $\mathrm{Ni}$ & C \\
\hline Core 9A & 0.000 & 0.000 & 1.071 & 0.055 & 1.164 & 0.607 & 0.158 & 0.0665 & 3.437 \\
\hline Core $10 \mathrm{~A}$ & 0.000 & 0.000 & 0.866 & 0.044 & 0.941 & 0.607 & 0.158 & 0.0665 & 4.170 \\
\hline Core $11 \mathrm{~A}$ & 0.000 & 0.000 & 0.724 & 0.037 & 0.796 & 0.607 & 0.158 & 0.0665 & 4.606 \\
\hline Blanket & 0.025 & 3.440 & 0.000 & 0.000 & 0.000 & 0.646 & 0.168 & 0.071 & 0.000 \\
\hline
\end{tabular}

The quoted critical masses of VERA 9A, 10A and $11 \mathrm{~A}$ are not corrected for core irregularities and edge effects, and these were estimated from the quoted corrections for the VERA $U^{235}$-fueled assemblies as about $2 \frac{1}{2} \%$.

The VERA Assemblies were cylindrical. Shape factors to convert the cylindrical masses to equivalent spherical masses were estimated by the method described by Davey. (1) The uncorrected critical masses and corrections are given in Table II.

In all cases the outer radius of the blanket was assumed to be $55.0 \mathrm{~cm}$. 
Table II

VERA CRITICAL MASSES AND CORRECTIONS

\begin{tabular}{|c|c|c|c|c|c|}
\hline $\begin{array}{c}\text { Assembly } \\
\text { Number }\end{array}$ & $\begin{array}{c}\text { Uncorrected } \\
\text { Critical } \\
\text { Mass } \\
(\mathrm{kg})\end{array}$ & $\begin{array}{c}\text { Critical Mass } \\
\text { Corrected for } \\
\text { Heterogeneity, } \\
\text { etc. (kg) }\end{array}$ & $\begin{array}{c}\text { Shape } \\
\text { Factor }\end{array}$ & $\begin{array}{c}\text { Spherical } \\
\text { Critical } \\
\text { Mass } \\
(\mathrm{kg})\end{array}$ & $\begin{array}{c}\text { Spherical } \\
\text { Core } \\
\text { Radius } \\
(\mathrm{cm})\end{array}$ \\
\hline $9 \mathrm{~A}$ & 24.1 & 24.7 & 0.98 & 24.2 & 11.08 \\
$10 \mathrm{~A}$ & 28.4 & 29.1 & 0.97 & 28.2 & 12.52 \\
$11 \mathrm{~A}$ & 33.1 & 33.9 & 0.97 & 32.9 & 13.98 \\
\hline
\end{tabular}

C. EBR-I Mark IV

$E B R-I$ is a small, fast power reactor whose fourth core loading consists of plutonium fuel rods. (14) The Mark-IV core is a fairly regular pseudocylinder, but there are a number of blanket regions of different composition; the regions are of different composition and thickness in the radial, bottom axial, and top axial directions. Conversion of such a complex real geometry to an equivalent spherical geometry is of dubious validity, but an attempt to estimate $k$ was made by carrying out three spherical DSN calculations. The core composition and dimensions were the same in each of these calculations, but the three reflector compositions corresponded to the blanket compositions in the radial, top axial, and bottom axial directions. No correction to the core critical mass was applied because of heterogeneity effects, but a shape factor of 0.98 was used. (1)

The compositions and dimensions of the various spherical regions used in the calculations are given in Tables III and IV.

Table III

EBR-I MARK-IV CORE COMPOSITION AND DIMENSIONS

\begin{tabular}{|c|c|c|c|c|c|c|c|c|c|}
\hline \multirow{2}{*}{$\begin{array}{c}\text { Core } \\
\text { Radius } \\
(\mathrm{cm})\end{array}$} & \multicolumn{7}{|c|}{ Composition (atoms/cm ${ }^{3}$ ) $10^{-22}$} \\
\cline { 2 - 10 } & $\mathrm{Pu}^{239}$ & $\mathrm{Pu}^{240}$ & $\mathrm{Fe}$ & $\mathrm{Ni}$ & $\mathrm{Cr}$ & $\mathrm{Al}$ & $\mathrm{Zr}$ & $\mathrm{Na}$ & $\mathrm{K}$ \\
\hline 10.70 & 1.274 & 0.069 & 0.425 & 0.065 & 0.107 & 0.151 & 0.910 & 0.178 & 0.377 \\
\hline
\end{tabular}

The three spherical DSN S4 calculations with the radial, top axial, and bottom axial reflectors gave values of $\mathrm{k}$ of $1.044,1.022$ and 0.999 , respectively. Since the cylindrical core has a length-to-diameter ratio of approximately unity, the portion of the core surface bounded by each of the above reflectors was in the ratio $4: 1: 1$; the $k$ values were weighted in this proportion. This crude calculation gave a weighted mean value of $k$ of 1.033 . 
Table IV

EBR-I MARK-IV BLANKET COMPOSITIONS AND DIMENSIONS

\begin{tabular}{|c|c|c|c|c|c|c|c|c|c|}
\hline \multirow{2}{*}{$\begin{array}{c}\text { Outer } \\
\text { Radius of } \\
\text { Region }(\mathrm{cm})\end{array}$} & \multicolumn{9}{|c|}{ Composition (atoms $/ \mathrm{cm}^{3}$ ) $\times 10^{-22}$} \\
\hline & $\mathrm{U}^{235}$ & $\mathrm{U}^{238}$ & $\mathrm{Fe}$ & $\mathrm{Ni}$ & $\mathrm{Cr}$ & $\mathrm{Al}$ & $\mathrm{Zr}$ & $\mathrm{Na}$ & $\mathrm{K}$ \\
\hline \multicolumn{10}{|c|}{ Radial Blanket } \\
\hline 12.00 & 0.004 & 1.686 & 0.458 & 0.069 & 0.116 & 0.000 & 0.871 & 0.184 & 0.389 \\
\hline 18.54 & 0.017 & 2.330 & 0.462 & 0.070 & 0.117 & 0.000 & 0.774 & 0.126 & 0.268 \\
\hline 24.59 & 0.000 & 0.000 & 3.457 & 0.525 & 0.875 & 0.328 & 0.000 & 0.064 & 0.136 \\
\hline 41.07 & 0.029 & 4.056 & 0.264 & 0.040 & 0.067 & 0.000 & 0.000 & 0.000 & 0.000 \\
\hline \multicolumn{10}{|c|}{ Top Axial Blanket } \\
\hline 30.40 & 0.004 & 1.695 & 0.435 & 0.066 & 0.110 & 0.000 & 0.897 & 0.181 & 0.383 \\
\hline 44.50 & 0.000 & 0.000 & 4.037 & 0.613 & 1.021 & 0.000 & 0.214 & 0.110 & 0.232 \\
\hline \multicolumn{10}{|c|}{ Bottom Axial Blanket } \\
\hline 19.74 & 0.004 & 1.695 & 0.435 & 0.066 & 0.110 & 0.000 & 0.897 & 0.181 & 0.383 \\
\hline 32.80 & 0.000 & 0.000 & 1.783 & 0.270 & 0.451 & 0.296 & 0.147 & 0.175 & 0.370 \\
\hline 44.13 & 0.029 & 4.056 & 0.264 & 0.040 & 0.067 & 0.000 & 0.000 & 0.000 & 0.000 \\
\hline
\end{tabular}

D. The RAPSODIE Assembly in ZPR-III

This assembly is a simplified mockup of the proposed French oxidefueled reactor RAPSODIE. The core is fueled with both plutonium and $\mathrm{U}^{235}$ and the experimental critical volume is 38.6 liters. (15) Using a $2 \%$ correction for heterogeneity and an estimated shape factor of 0.97 , we derive a spherical, homogeneous critical volume of 38.2 liters. The core and blanket dimensions used in the DSN calculation are given in Table V.

Table V

RAPSODIE MOCKUP COMPOSITION AND DIMENSIONS

\begin{tabular}{|c|c|c|c|c|c|c|c|c|c|c|}
\hline \multirow{2}{*}{$\begin{array}{c}\text { Outer } \\
\text { Radius of } \\
\text { Region }(\mathrm{cm})\end{array}$} & \multicolumn{8}{|c|}{ Composition (atoms/cm ${ }^{3}$ ) $10^{-22}$} \\
\cline { 2 - 10 } & $\mathrm{U}^{235}$ & $\mathrm{U}^{238}$ & $\mathrm{Pu}^{239}$ & $\mathrm{Pu}^{240}$ & $\mathrm{Fe}$ & $\mathrm{Cr}$ & $\mathrm{Ni}$ & $\mathrm{Mo}$ & $\mathrm{Al}$ & $\mathrm{O}$ \\
\hline 20.9 & 0.504 & 0.336 & 0.156 & 0.007 & 1.420 & 0.181 & 0.092 & 0.000 & 1.029 & 1.957 \\
32.8 & 0.005 & 2.163 & 0.000 & 0.000 & 0.857 & 0.222 & 0.113 & 0.652 & 0.767 & 0.000 \\
65.8 & 0.006 & 2.977 & 0.000 & 0.000 & 0.446 & 0.115 & 0.059 & 0.000 & 0.693 & 0.000 \\
\hline
\end{tabular}

\section{RESULTS}

The results of the DSN calculations are given in Table VI. S4 and S8 calculations were performed for GODIVA, JEZEBEL, and POPSY. The difference in the values of $k$ obtained by means of these two approximations decreased with increasing core radius. These data were then used to estimate the values of $k$ that would be obtained for the other reactors if S8 calculations were used. 
Table VI

CALCULATED VALUES OF $\mathrm{k}$

\begin{tabular}{|l|c|c|c|c|}
\hline \multicolumn{1}{|c|}{ Reactor } & Fuel & $\begin{array}{c}\mathrm{k}(\mathrm{S} 4)(\mathrm{a}) \\
-\mathrm{k}(\mathrm{S} 8)\end{array}$ & $\mathrm{k}(\mathrm{S} 4$ calc $)$ & $\mathrm{k}(\mathrm{S} 8 \text { calc })^{(\mathrm{a})}$ \\
\hline GODIVA & $\mathrm{U}^{235}$ & 0.003 & 1.015 & 1.012 \\
TOPSY & & 0.007 & 1.029 & 1.022 \\
JEMIMA, 53.6 & & 0.001 & 1.015 & 1.014 \\
JEMIMA, 37.7 & $\downarrow$ & 0.000 & 1.001 & 1.001 \\
JEMIMA, 29.0 & $\mathrm{Pu}$ & 0.000 & 0.991 & 0.991 \\
\hline JEZEBEL & & 0.012 & 1.029 & 1.022 \\
POPSY & & 0.001 & 1.062 & 1.050 \\
Pu/U & & 0.001 & 1.054 & 1.013 \\
VERA 9A & & 0.001 & 1.039 & 1.053 \\
VERA 10A & 0.000 & 1.032 & 1.032 \\
VERA 11A & & 0.001 & 1.033 & 1.032 \\
EBR-I Mark IV & $\downarrow$ & 0.000 & 1.030 & 1.030 \\
\hline RAPSODIE & Pu+ $\mathrm{U}^{235}$ & 0.010 & 1.044 & 1.034 \\
\hline $\mathrm{U}^{233} / \mathrm{U}^{238}$ & $\mathrm{U}^{233}$ & 0.010 & 1.027 \\
$\mathrm{U}^{233} / \mathrm{U}^{235}$ & $\downarrow$ & 0.010 & 1.037 & \\
\hline
\end{tabular}

(a) Calculated for GODIVA, JEZEBEL, and POPSY, and estimated for the other reactors

\section{DISCUSSION AND CONCLUSIONS}

(a) The values of $\mathrm{k}$ for the small assemblies fueled entirely with $\mathrm{U}^{235}$ are calculated with about the same accuracy as for the larger, diluted ZPR-III assemblies previously examined. $(1,3)$ This is true for the bare JEMIMA and GODIVA reactors as well as for the reflected TOPSY. In terms of calculation of critical mass, this indicates an accuracy of about $6 \%$ or better for all reactors fueled solely with $\mathrm{U}^{235}$ up to a mass of $580 \mathrm{~kg}$. This does not imply that the nuclear data are free from significant errors.

(b) The values of $\mathrm{k}$ for all the reactors fueled with plutonium are greater than unity, being on average about $3 \frac{1}{2} \%$ greater. Somewhat surprisingly, and perhaps fortuitously, this is true for the RAPSODIE reactor, which is fueled with both $\mathrm{U}^{235}$ and plutonium. For the small reactors considered here, an error of $3 \frac{1}{2} \%$ in the calculated value of $\mathrm{k}$ means prediction of critical masses that would be about $6 \%$ to $10 \%$ smaller than would be obtained by experiment. If the same discrepancy of about $3 \frac{1}{2} \%$ in $\mathrm{k}$ also occurs in large plutonium-fueled reactors, this could result in errors of critical mass varying from about $20 \%$ to $30 \%$.

(c) The values of $k$ for the two $\mathrm{U}^{233}$-fueled reactors are about $3 \%$ greater than unity. 


\section{REFERENCES}

1. W. G. Davey, k Calculations for 22 ZPR-III Fast Reactor Assemblies Using ANL Cross-section Set 635, ANL-6570 (May 1962)。

2. W. G. Davey, A Critical Comparison of Measured and Calculated Fission Ratios for ZPR-III Assemblies, ANL-6617 (Sept 1962).

3. W. G. Davey, A Comparison of Experimental and Calculated Prompt Neutron Lifetimes and Central Reactivity Coefficients in ZPR-III Assemblies and their Relationship to Other Reactor Parameters, ANL-6682 (June 1963).

4. S. Yiftah, D. Okrent, and P.A. Moldauer, Fast Reactor Cross Sections, Pergamon Press, New York (1960).

5. J. C. Hopkins and B.C. Diven, Capture-to-fission Ratios for Fast Neutrons in $\mathrm{U}^{2.33}, \mathrm{U}^{235}$ and $\mathrm{Pu}^{239}$, IAEA - Sponsored Seminar on the Physics of Fast and Intermediate Reactors, Vienna, 1, SM-18/55, 111 (1962).

6. Ibid., A. Moat, D.S. Mather, and P. Fieldhouse, The Number of Prompt Neutrons from $\mathrm{U}^{235}$ Fission over the Range 0.04 to $3.0 \mathrm{MeV}$, 1, SM-18/18,139(1962)。

7. Ibid., D. Butler, S. Cox, J. Meadows, J. Roberts, A. Smith, and J. Whalen, Experimental Study of Fission Properties Utilized in Reactor Design, 1, SM-18/36, 125 (1962).

8. Ibid., B.C. Diven and J.C.Hopkins, Numbers of Prompt Neutrons per Fission for $\mathrm{U}^{233}, \mathrm{U}^{235}, \mathrm{Pu}^{239}$, and $\mathrm{Cf}^{252}, 1, \mathrm{SM}-18 / 56,149(1962)$.

9. Ibid., H. H. Hummel and A. L. Rago, An Accurate Treatment of Resonance Scattering in Light Elements in Fast Reactors, 1, SM $18 / 45$ $231(1962)$.

10. Tbid., D. Meneghetti, Recent Advances and Problems in Theoretical Analyses of ZPR-III Fast Critical Assemblies, 1, SM-18/37,457 (1962)。

11. J. L. Rowlands, Personal Communication.

12. W. H. Roach, Computational Survey of idealized Fast Breeder Reactors, Nuclear Science and Engineering, 8 , 621 (1960).

13. J.W.Weale, M.H. McTaggart, H. Goodfellow, and W. Paterson, Oper ating Experience with the Zero-Energy Reactor VERA, IAEA Symposium on Exponential and Critical Experiments, Amsterdam, Paper SM-42/19 (Sept. 1963).

14. R. R. Smith, R. O. Haroldsen, R. A. Horne, and R。G. Matlock, The Breeding Ratio of a Plutonium Loading in EBR-I, ANL-6789 (1964)。

15. Argonne National Laboratory Reactor Development Program Progress Report, ANL-6801 (Oct 1963)。 


\section{APPENDIX I}

GROUP CROSS SECTIONS FOR COPPER (in barns)

\begin{tabular}{|c|c|c|c|c|c|c|c|c|c|c|}
\hline \multirow{2}{*}{ Group } & \multirow{2}{*}{$\sigma_{t r}$} & \multirow{2}{*}{$\sigma_{n} \gamma$} & \multirow{2}{*}{$\sigma_{\mathrm{er}}$} & \multicolumn{7}{|c|}{$\sigma_{n, n^{\prime}} j \rightarrow k$} \\
\hline & & & & $\mathrm{k}=0$ & 1 & 2 & 3 & 4 & 5 & 6 \\
\hline 1 & 2.3 & 0.00 & 0.047 & 0.124 & 0.347 & 0.444 & 0.356 & 0.212 & 0.105 & 0.076 \\
\hline 2 & 2.4 & 0.00 & 0.076 & 0.172 & 0.371 & 0.373 & 0.137 & 0.064 & 0.027 & 0.018 \\
\hline 3 & 2.45 & 0.01 & 0.12 & 0.144 & 0.218 & 0.175 & 0.104 & 0.051 & 0.023 & 0.015 \\
\hline 4 & 3.0 & 0.01 & 0.19 & 0.054 & 0.059 & 0.039 & 0.021 & 0.010 & 0.004 & 0.003 \\
\hline 5 & 3.5 & 0.01 & 0.23 & & & & & & & \\
\hline 6 & 4.15 & 0.015 & 0.28 & & & & & & & \\
\hline 7 & 5.0 & 0.02 & 0.33 & & & & & & & \\
\hline 8 & 5.75 & 0.03 & 0.36 & & & & & & & \\
\hline 9 & 6.6 & 0.04 & 0.40 & & & & & & & \\
\hline 10 & 22.0 & 0.054 & 3.00 & & & & & & & \\
\hline 11 & 7.8 & 0.079 & 0.47 & & & & & & & \\
\hline 12 & 7.9 & 0.109 & 0.44 & & & & & & & \\
\hline 13 & 8.9 & 0.163 & 0.53 & & & & & & & \\
\hline 14 & 11.5 & 0.227 & 0.45 & & & & & & & \\
\hline 15 & 9.05 & 0.562 & 0.34 & & & & & & & \\
\hline $16 ́$ & 8.1 & 0.390 & 0.00 & & & & & & & \\
\hline
\end{tabular}

The group bouncaries are those of Yiftah et al. (4) 